\title{
Toprakta Ağır Metal Gideriminde Solucanların Kullanımı
}

\author{
Berrak TACİROĞLU, Emine Erman KARA*, Tufan SAK \\ Niğde Üniversitesi, Mühendislik Fakültesi, Çevre Mühendisliği Bölümü, Niğde
}

Geliş (Received): 08.12.2015

Kabul (Accepted): 09.04.2016

\begin{abstract}
ÖZET: Ağır metal kirliliği, toprakta oluşan kirlilikler arasında en zor giderilen kirliliklerden birisidir. Ağır metaller toprağa oluşum sırasında ana materyalin yapısında bulunmaları nedeni ile geçebildikleri gibi maden, endüstri ve tarımda kullanılan kimyasal maddeler gibi çeșitli kirleticiler ile de toprağa ulaşabilmektedirler. Toprakta bulunan ağır metallerin yüksek konsantrasyonları toprak ekosisteminde bulunan canlılara toksik etki yapmaları yanında, toprakta biyolojik ve biyokimyasal reaksiyonları etkileyerek/engelleyerek toprak özelliklerinde bozulmaya da neden olabilmektedirler. $\mathrm{Bu}$ durum besin elementi döngüsünde aksamalar ya da bozulmalar olarak ortaya çıkabilmektedir. Ağır metaller yer altı sularına sızdığı takdirde temiz su kaynaklarını da kirletebilmektedir. Ağır metaller toprak ekosistemindeki etkisi yanında, gıda zinciri ile insana ulaştıklarında birikim etkisi nedeni ile akut veya kronik hastalıklara neden olabilmektedirler. Açıklanan zararları nedeni ile toprakta ağır metal konsantrasyonunun kritik düzey üzerinde bulunması istenmez. Bahsedilen etkiler ile birlikte; toprakta biyolojik canlılığın devamı, toprak sağlığının ve kalitesinin korunması, tarımsal sürdürülebilirliğin devamı için toprakta oluşan ağır metal kirliliğinin bertaraf edilmesi gerekmektedir. Toprakta ağır metal kirliliğini bertaraf etmek için; izolasyon-immobilizasyon, mekanik ayırma, pirometalurjik, elektrokinetik, toprağı yerinde (in-situ) temizleme, toprak yıkama ve biyoremediasyon teknolojileri kullanılmaktadır. Derleme olarak hazırlanan bu çalışmada biyoremediasyon tekniklerinde kullanılan toprak solucanlarının topraktan ağır metal giderimi ile ilgili yapılan araştırma sonuçları konusunda bilgi verilmektedir.
\end{abstract}

Anahtar Kelimeler: Toprak kirliliği, ağır metal, solucan, giderim, biyoremediasyon

\section{Using Earthworms to Remove Heavy Metal in Soil}

\begin{abstract}
Heavy metal pollution in soil is one of the hardest removable pollution among the pollutions occurring in soil. Heavy metals, such as exist able to switch within the main material building during the formation of the soil, with various pollutants such as chemicals used in mine, industry and agriculture can reach to the soil. High concentration of heavy metals in the soil could be toxic to soil ecosystem, could cause deterioration of soil properties by blocking biological and biochemical reactions in soil. This situation can occur as disruptions and deteriorations in nutrients cycle. Heavy metals can also contaminate clean water sources in ground if the groundwater is leaked. Besides the effect of heavy metals in soil can cause acute or chronic diseases in food chain due to accumulation effects on human. Because of negative effects described above, the levels greater than critical level of concentration of heavy metals in the soil is not desirable. With mentioned effects; heavy metal contamination in soil needs to be removed to continue viability of biological, to preserve soil health and quality and to continue agricultural sustainability. To eliminate the heavy metal pollution in the soil; insulation-immobilization, mechanical separation, pyro metallurgical, electro kinetic, soil in place cleaning, soil washing and bioremediation Technologies are used. In this review study the results of researches about the earthworms were used in bioremediation techniques for heavy metal removal.
\end{abstract}

Key Words: Soil pollution, heavy metal, earthworm, removal, bioremediation

\section{GíRiș}

Ağır metalin tanımı daha çok çevresel problemler olduğunda ortaya çıkmakta ve nispeten yüksek yoğunluğa sahip ve düşük konsantrasyonlarda bile toksik veya zehirleyici olan metal olarak tarif edilmektedir. Gerçekte ağır metal tanımı fiziksel özellik açısından yoğunluğu $5 \mathrm{~g} / \mathrm{cm}^{3}$ ten daha yüksek olan metaller için kullanılmaktadır. Bu grubun içine kurşun, kadmiyum, krom, demir, kobalt, bakır, nikel, civa ve çinko olmak üzere tan fazla metal girmektedir. $\mathrm{Bu}$ elementler doğaları gereği yerkürede genellikle karbonat, silikat ve sülfür halinde stabil bileşik olarak veya silikatlar içinde bağlı olarak bulunurlar (Okcu ve ark., 2009). Toprak, ana materyalin fiziksel, kimyasal ve biyolojik ayrışma işlemleri sonucu oluşan, belli fiziksel, kimyasal ve biyolojik özelliklere sahip olan, içinde ve üzerinde canlıları barındıran, bitkilere durak yeri olan ve besin temin eden, canlı dinamik üç boyutlu bir sistem olarak tanımlanmaktadır. Bu özelliklere sahip olan toprak, doğada bulunan hava ve su ekosistemi ile birlikte üç ana ekosistemden birini oluşturmaktadır. Doğada bulunan ana ekosistemlerden biri olan toprak, tamponlama özelliği nedeni ile toprağa ulaşan kirleticileri tutma, yani filtrasyon özelliği ile kirleticileri tutarak, su ve hava ekosisteminin kirliliğini de önleyebilmektedir.

Toprak kirliliği, toprakların fiziksel, kimyasal ve biyolojik özelliklerinde meydana gelen bozulma olarak tanımlanmaktadır. Toprakların oluşumu sırasında ayrışmanın gerçekleștiği ana materyalin bünyesinde 
bulunan kirleticilerden kaynaklanan kirlilik doğal kirlilik olarak tanımlanır iken, toprağa dışarıdan ilave edilen maddelerden (katı, sıvı, gaz) kaynaklanan kirlilik ise doğal olmayan kirlilik olarak tanımlanmaktadır. Toprakta meydana gelen kirlilik, topraktaki fiziksel, kimyasal ve biyolojik olayların gerçekleşmesini engelleme ve/veya yön değiştirmesine neden olabilmektedir. Toprakta kirliliğe neden olanlar; tarımda kullanılan kimyasallar (pestisit ve kimyasal gübreler), endüstriyel atıklar, nükleer atıklar, tıbbi atıklar, evsel atıklar, maden işletme atıkları olarak siralanabilmektedir. Toprak kirliliğine neden olan kirleticiler, toprakta ayrışma işlemine uğrayabilir özellikte ise, ayrışarak yok olabilir iken, toprakta kirliliğe neden olan ağır metaller ayrışarak başka bileşiklere dönüşmedikleri için, toprakta giderilemeyen kirlilik olarak kabul edilmektedir. Ağır metaller toprakta fosfor, karbonat ve bikarbonat bileşikleri ile bir araya gelerek bitkiler tarafindan alınamaz forma dönüşebilmektedirler. Bu nedenle de diğer kirleticilere göre toprakta ağır metal kirliliği ayrı bir öneme sahip bulunmaktadır. Toprakta oluşan ağır metal kirliliği sonucunda toprakta reaksiyonların gerçekleşememesi, doğada besin elementleri döngüsünün tamamlanamaması ile sonuçlanabilmektedir. Böyle bir durumda, toprak ekosisteminde meydana gelen bozulma diğer ekosistemleri de olumsuz etkileyebilmektedir. Bu nedenle toprak kirliliğinin olmaması ve/veya toprak kirliliği meydana gelmiş ise bu kirliliğin giderilmesi ayrı bir önem taşımaktadır. Toprakta oluşan ağır metal kirliliği, kirlilikler içerisinde gideriminin zor olması, insan ve çevre sağlığı açısından önemli derecede tehlike oluşturan ve sık karşılaşılan kirlilikler arasında yer almaktadır.

A ğır metaller inorganik kimyasal tehlikelerin tam tanımlanmamış bir grubunu olușturur ve kirlenmiş bölgelerde en yaygın bulunan ağır metaller $\mathrm{Pb}, \mathrm{Cr}, \mathrm{As}$, $\mathrm{Zn}, \mathrm{Cd}, \mathrm{Cu}, \mathrm{Hg}$, Ni (Wuana ve Okieimen, 2011)'dir. Ağır metaller, araçlardan çıkan egzoz gazları, pestisit kullanımı, kimyasal gübreleme, ağır metal içerikli arıtma çamurlarının toprağa serilmesi, kimyasal atıkların toprağa gömülmesi, açık maden işletmeciliği gibi uygulamalar sonucunda toprağa ulaşmaktadırlar.

Kentsel ekosistemlerdeki potansiyel toksik metallerin taşınım, yayılım, birikim, ve dağılımına ilişkin bilgiler, potansiyel çevre ve sağlık etkileri değerlendirmesinde ve eser metal kirlilik değerlendirmesinde önemli rol oynamaktadır. Toprakla temas ve ağır metallere maruz kalma, insanların toprakları nasıl kullandığına bağlıdır (Paggio ve ark., 2008). Toprak parçacıklarının özellikle çocuklar için elağı faaliyetleri ile kazara yenmesi metal maruziyetinin önemli bir yolu olarak değerlendirilmektedir. Toprağın ağız yolu ile günlük alım miktarının 50 ile $200 \mathrm{mg} \mathrm{gün}^{-1}$ aralığında olduğu tahmin edilmektedir. Ancak, pika davranışına (yenmeyecek maddelerin kasıtlı olarak yenmesi) sahip olan bazı çocukların bir günde 20 gr a kadar toprak yiyebildiği kanıtlanmıştır. Çocukların yaşadığı kirlenmiş toprakları yemekten kaynaklanan akut zehirlenmenin sıklığı bilinmemektedir. ABD Çevre Koruma Ajansı, 1 ile 6 yaş arasındaki çocukların günlük toprak alım miktarının $100 \mathrm{mg}$ gün $^{-1}$ değerinde olduğunu açıklamıștır. Potansiyel metal kirliliğine sahip alanlarda çocukların topraklara maruziyeti, metal düzeylerinin belirlenmesi ve potansiyel metal alımının değerlendirilmesi büyük bir endișe kaynağıdır. Bunların bir risk oluşturması için yenmiş durumda olan kirleticilerin, biyolojik olarak kullanılabilir yani sindirim sisteminde çözünebilir ve kan dolaşımında absorbe olması gerekmektedir (Pelfrene ve ark.,2015).

Ağır metallerin insan bünyesine ulaşabildiği bir diğer yol ise bitkiler aracılığı ile olmaktadır. Bitkiler atmosferden, gübrelerden, atıksu ve çamurlardan veya tarımda kulanılan inorganik pestisitlerden toprağa bulaşmış olan ağır metalleri derişimlerine bağlı olarak biriktirme eğilimindedirler (Vural, 1993). Tarım alanlarının sulanmasında atık su, birçok ülkede yaygın olarak kullanılmaktadır. Kısmen arıtılmış veya arıtılmamış suyun uzun süre kullanılması toprakta ağır metal birikimine yol açabilmektedir. Atık su ile sulama sebzelerin ağır metaller ile kirlenmesinin ana nedenlerinden biridir (Xue ve ark., 2012). Toprağa ulaşan ağır metaller gıda yolu insan vücuduna girebilmekte, aynı zamanda bu bitkilerin hayvanlara yem kaynağı olarak verilmesi durumunda ise hayvanın etinden ve sütünden gida zinciri ile insanlara ulaşmaktadır. Bu maddelerin bir kısmı yüksek dozda vücuda girmesi halinde zehirleyici etki yapabilirken, bazıları düşük dozda alınsalar bile biyolojik birikim nedeniyle zararlı etkilere yol açabilmektedirler. Bu olay bir biyolojik birikim, biyolojik artım olarak adlandırılmaktadır (Çobanoğlu ve Güler, 1997).

Toksik düzeydeki ağır metallerin insan bünyesinde birikmesi sonucunda, metalin türüne ve miktarına bağl1 olarak insanlarda kusma, kanama, sarılık, kansızlık, böbrek yetmezliği, akli bozukluklar, deri lezyonları ve kırılgan kemik yapısı gibi birçok sağlık bozukluğu görülebilmektedir (Öktüren Asri ve Sönmez, 2006). Bahsedilen bu olumsuz etkiler, toprakta bulunan ağır metallerin bitkiler tarafından alınabilir formda bulunması ile gerçekleşmektedir. Diğer bir deyişle toprakta bulunan ağır metallerin bitkiler tarafindan alınabilir veya alınamaz formda olması meydana gelecek kirliliğin boyutlarını belirlemektedir.

Yukarıda bahsedildiği gibi ağır metallerin sebep olduğu toprak kirlilik faktörleri gıda güvenliğini tehdit edip risk oluştururken, toprak florasını ve toprak kompozisyonunu da bozmaktadır. Topraktaki mikroorganizmaların ve toprak solucanlarının azalmasına, toprağın biyotik yeteneğinin de azalmasına sebep olmaktadır (Çağlarırmak ve Hepçimen, 2010 ). Ağır metallerin toprakta birikmesi sadece toprak verimliliği ve ekosistem faaliyetleri üzerinde etkili olmayı, bitki bünyesindeki fotosentez, solunum, büyüme ve gelişme gibi birçok metabolik olayları etkilemeleri nedeniyle bitki sağlığını da önemli düzeyde etkilemektedir (Öktüren Asri ve Sönmez, 2006 ). 
Toprağa direkt yollarla ulaşan ağır metallerin yanı sıra, atmosferde çeşitli sebeplerle (endüstri, egzoz gazı vb.) oluşan ağır metal kirliliği, yağmurlar vasıtasıyla toprağa ulaşmakta ve bu ağır metaller topraktan yıkanarak yer altı suyu kirliliğine sebep olmaktadır. Bu nedenle doğaya bir şekilde bırakılan ağır metaller canlı yaşamı için vazgeçilmez olan hava, su ve toprağ 1 aynı anda olumsuz etkilemektedirler. Tüm bu olumsuz etkiler nedeniyle toprakta meydana gelen ağır metal kirliliğinin giderilmesi son derece önem kazanmaktadır.

\section{KIRLENMISS TOPRAKLARDA YAPILAN UYGULAMALAR}

Ağır metallerle kirlenmiş topraklarda öncelikli olarak, ortamda bulunan ağır metal kirliliğinin gideriminin sağlanması gerekmektedir. Ancak, giderim maliyetinin yüksek olması ya da kirlenmiş bölgenin temizlenemeyecek kadar geniş olması durumunda, ilk etapta kirliliğin geniş alanlara yayılımının önlenmesi sağlanmalı ve/veya tarımsal üretimde kullanımının önüne geçilmelidir. Bunun için; kirleticiye müdahalede bulunmayarak, kirlenmiş alanın kullanımını yasaklamak, kirleticiyi bölge içerisinde immobilize etmek ve bölgeyi kontrol altına almak, kirlenmiş toprağı nihai bertaraf sahasına taşıyarak depolamak, kirlenmiş toprağın ormanlık alana terk edilmesi alınacak önlemler arasında iken, kirliliğin giderimi için toprağın yerinde veya bölge dışında giderimi sağlamak gerekmektedir.

Kirlenmiş toprakların temizlenmesi amacıyla kullanılan fiziksel, kimyasal, termal ve biyolojik işlemleri içeren birçok yöntem bulunmaktadır. Bu yöntemler; izolasyon ve immobilizasyon teknolojileri, mekanik ayırma teknolojileri, pirometalurjik teknolojiler, elektrokinetik teknolojiler, toprağı su/sıv1 ile yerinde temizleme teknolojileri, toprak yıkama teknolojileri ve biyoremediasyon teknolojileri olarak sıralanabilmektedir (Vanlı ve Yazgan, 2008).

\section{IZOLASYON TEKNOLOJILERI}

IMMOBILIZASYON

İzolasyon ve immobilizasyon teknolojileri, topraktaki kirleticilerin hareketlerinin minimize edilmesi için uygulanmaktadırlar. Çelik, çimento, bentonit ve harç duvarlardan yapılan fiziksel bariyerler kirlenmiş bölgenin üzerini kaplamak ve kirleticinin toprak profilinde yatay ve düşey yöndeki hareketini sınırlamak için yaygın şekilde kullanılmaktadırlar (Kocaer ve Başkaya, 2003). Yöntemin yüksek maliyetli olması nedeniyle geniş alanlarda kullanılması dezavantaj yaratırken, kirliliğinin gideriminden ziyade daha çok kirliliğin yayılmaması amaçlı bir uygulama olması nedeniyle, topraktaki ağır metal kirliliği giderimi için uygun bir teknoloji olarak görülmemektedir.

\section{MEKANIK AYIRMA TEKNOLOJILERİ}

Ayırma santrifüj gücüne dayalı hidrosiklonlar, gravimetrik çöktürmeye dayalı akışkan yatak ayırıcılar, kirli partiküllerin farklı yüzey özelliklerine dayanan flotasyon ayırıcılar ve metallerin manyetik özelliklerine dayanan manyetik ayırıcılar ile gerçekleştirilmektedir (Kocaer ve Başkaya, 2003). Geniş alanlarda uygulanması mümkün görülmemektedir.

\section{PIROMETALURJIK TEKNOLOJILER}

Pirometalurjik proseslerde kirlenmiş topraktaki metalleri buharlaştırmak için yüksek sıcaklık firınları kullanılmaktadır. $\mathrm{Bu}$ metotlar özellikle yüksek sıcaklıklarda metalik formuna kolayca dönüşen civa için uygundur (Kocaer ve Başkaya, 2003). Bu nedenle yüksek sıcaklıklarda kolaylıkla form değiştirmeyen diğer ağır metaller için kullanımı avantajlı görülmemektedir.

\section{ELEKTROKINETIK TEKNOLOJILER}

Kirleticileri yüklü türler olarak mobilize etmek için toprağa yerleştirilen elektrotlar arasına düşük yoğunluklu doğru akım uygulanmasıyla gerçekleştirilir (Kocaer ve Başkaya, 2003).Geniş alanlarda uygulanması mümkün görülmektedir.

\section{TOPRAĞI SU/SIVI ILE YERİNDE TEMIZLEME TEKNOLOJILERI \\ Kirleticileri topraktan ayıracak bir siv1} uygulanmasıyla gerçekleştirilebilir. $\mathrm{Bu}$ yöntemde topraktaki kirleticiler su ile veya uygun sulu çözeltilerle ekstrakte edilirler (Kocaer ve Başkaya, 2003). Su ile temizleme yöntemi yalnızca suda çözünebilen metal gideriminde etkili olurken, diğer metallerin giderimi için farklı çözücülerin kullanılması gerekmektedir. Bunun dışında geniş alanlarda uygulanması mümkün görülmemektedir.

\section{TOPRAK YIKAMA TEKNOLOJILERI}

Toprak yıkama teknolojisi, kazılmış toprağa uygulanan ve topraktaki çok sayıda organik, inorganik ve radyoaktif kirleticilerin uzaklaştırılmasında etkili, klasik kimyasal-fiziksel ekstraksiyon ve ayırma proseslerini içeren su bazlı bir arıtım teknolojisidir (Kocaer ve Başkaya,2003). Geniş alanlarda uygulanması mümkün görülmemektedir.

\section{BIYYOREMEDİASYON TEKNOLOJILERI}

Biyoremediasyon, kirlenmiş toprak ve suların daha çevre dostu bir şekilde kirliliğinin giderimi için bitkiler, topraksolucanları, mantar ve bakteri gibi makro ve mikroorganizmaların kullanılması yöntemidir (Anonim, 2016).

Biyoremediasyon, diğer remediasyon tekniklerinde (solidifikasyon/stabilizasyon, vitrifikasyon, toprak yıkama, elektrokinetik teknolojiler, vb.) olduğu gibi kirletici bir fazdan diğerine dönüștürmediği için daha kalıcı bir çözüm yöntemidir. Biyoremediasyon yönteminde kirleticiler biyolojik aktivitelerle karbondioksit ve su gibi zararsız son ürünlere dönüştürülmektedirler. Proses biyolojik aktiviteye dayalı olarak gerçekleştiği için ortamda yeterli organizma bulunmas1, biyoremediasyon boyunca oluşacak ürünlerin toksisite yaratmaması, organizmaları 
inhibe edici kimyasallar mevcutsa seyreltilmesi büyük önem taşımaktadır. Ayrıca, organizmaların büyümesini ve aktivitesini arttıracak besin elementleri, $\mathrm{O}_{2}$, diğer elektron alıcılar, uygun nem oranı, sıcaklık, karbon ve enerji kaynağı sağlanmalıdır (Dindar ve ark., 2010).Bu nedenle canlıların yaşayacağı toprak koşulları uygun değilse yöntem başarılı olarak uygulanamamaktadır.

Biyoremediasyon teknolojileri kapsamında toprak ve suda meydana gelen kirliliklerin giderimini sağlamak amacıyla bitkilerin kullanılması, fitoremediasyon yöntemi olarak adlandırılmaktadır. Fitoremediasyon yöntemlerinden biri olan fitoekstraksiyon, potansiyel olarak topraktan mikro elementleri giderebilir, ancak yüksek metal konsantrasyonlarına sahip küçük bir biyokütleyi tolere edebilen yüksek akümülatör bitkiler genellikle yalnızca 1 ya da 2 metali tolere edebilir ve iklim koşullarına duyarlıdır (Tandy, 2009). Bitki kullanılarak topraklardan alınan ağır metal alma işleminde amaç, toprak tarafindan tutulmuş halde bulunan ağır metallerin daha kontrol edilebilir ve taşınabilir forma dönüştürülmesidir. $\mathrm{Bu}$ nedenle fitoremediasyon yöntemi, nihai bir uzaklaştırma veya giderme yöntemi olarak düşünülmemektedir (Vanlı ve Yazgan, 2008). Ayrıca, fitoremediasyon ile topraktan ağır metal alımı gerçekleştirildiğinde kullanılan bitkilerin topraktan uzaklaştırılması gerekmektedir.

Topraktaki ağır metal giderimini sağlamak için biyoremediasyon teknolojileri uygulamalarında bitkilerin yanı sıra çeşitli mikro ve makro canlılar kullanılmaktadır. $\mathrm{Bu}$ canlılardan biri olan topraksolucanlarının toprakta ağır metal giderimindeki etkisi bu yazıda açıklanacaktır.

\section{TOPRAK SOLUCANLARININ TOPRAĞA ETKİSI}

Toprak solucanları en önemli toprak organizmaları olup, toprak verimliliğinin artırılmasında rol oynarlar. Genel olarak toprak solucanlarının toprağa olan etkileri fiziksel, kimyasal ve biyolojik yollarla olmaktadır. Toprak solucanlarının biyolojik etkisi, mikrobiyal konsantrasyonların ve diğer aktivitelerin uyarılması şeklinde, kimyasal etkisi; mineral ve organik madde dekompozisyonunun artması, fiziksel etkisi; horizonlar arasındaki minerallerin taşınarak agregat yapısının değişmesi, havalandırma ve agregasyon şeklindedir (Dindar, 2008).

Toprak solucanları hem doğal hem de tarımsal ekosistemlere önemli hizmetler sağlayan canlılardır. Toprak solucanlarının bitki besin maddesi mineralizasyonu yoluyla toprak verimliliğine önemli katkıları olmaktadır. Toprak solucanlarının verimlilik üzerindeki direkt etkileri, bitki artıklarının parçalanma ve mineralizasyonunun geliştirilmesini sağlamasıdır.

İndirekt etkileri ise, toprak gözenekliliğinin, toprak organik maddesinin ve suya dayanıklı agregat stabilitesinin artması yoluyla toprak-su ilişkilerinin geliştirilmesine olan katkılarıdır. Topraklarda bulunan topraksolucanı varlığının korunması ve artırılması ile, hem kimyasal gübre maliyetleri hem de kimyasal gübre kullanımının çevre üzerindeki olumsuz etkileri azalmaktadır (Bellitürk, 2013).

Toprak solucanı aktivitesi sonucunda, organik maddenin mineralizasyonundan açığa çıkan yarayışlı azot formlarının yanı sıra, bu canlıların ölümünden sonra vücut dokularının hızlıca ayrışmasıyla da ortama azotlu bileşikler bırakılmaktadır. Ayrıca, yaşadıkları süre boyunca metabolik ürünleri aracılığ 1 ile ortamda azotlu bileşikler bulunabilmektedir. Topraklara protein içeren ölü dokular dışında metabolik ürünlerden (mukus, üre, ürik asit, amonyak) bırakılan azot miktarı 18-92 kg ha-1 $\mathrm{yll}^{-1}$ düzeyindedir. $\mathrm{Bu}$ miktarlar, organizmanin türüne, mevsimsel değişimlere, populasyonun büyüklük ve aktivitesine bağlı olarak değişmektedir (Dindar, 2008).

TOPRAKTA AĞIR METAL GIDERIMINDE TOPRAK SOLUCANLARININ ETKISI

Toprak solucanları metallerce kirletilmiş topraklarda metal mobilitesini ve bitkiye metal transferini artırmakla beraber toprak faunasının diğer üyelerine göre metal toksisitesine karşı daha dirençli olup, metalleri bünyelerinde biriktirebilmekte ve alınabilir metal miktarını artırabilmektedirler.

Toprak solucanı dokularında ağır metal birikimi, toprak solucanlarının biriktirme kapasitelerine, metallerin toprak solucanlarındaki toksisitesine, ağır metal çeşidine ve toprak solucanlarının ekolojik kategorilerine göre değişkenlik göstermektedir. Örneğin, endojeik türler Cd'u epijeik ve anesik türlere göre daha yüksek miktarlarda biriktirirken, anesik türler Zn'yu diğer iki türden daha yüksek miktarlarda biriktirmektedirler. Lumbricus rubellus $\mathrm{Cu}$ kirliliğini Aporrectodea caliginosa dan daha çok tolere etmektedir. Eisenia fetida ların ise en az toksisiteyi $\mathrm{Pb}$ da gösterdikleri belirlenmiştir (Hepşen Türkay, 2010).

\section{TOPRAKTA AĞIR METAL GIDERIMINDE TOPRAKSOLUCANLARININ ETKISİ ÜZERİNE YAPILAN ÇALIŞMALAR}

Topraktaki ağır metalin toprak solucanları aracılığ1 ile giderimi konusunda yapılan çalışmalar, arıtma çamurlarının farklı organik atıklarla birlikte solucanlar kullanılarak kompostlaştırma (vermikompost) işlemi sırasında toprak solucanları bünyesinde birikimi konusunda yoğunlaşmıştır.

Hepşen Türkay (2010), findık zurufu ve arıtma çamurunun toprak solucanları ile kompostlanması ile elde edilen vermikompostun sera ve tarla koşullarında toprakların biyolojik özelliklerinde meydana getirdiği etkilerin belirlenmesi amacı ile 90 günlük inkübasyon çalışması sonucunda, arıtma çamurundan kaynaklanan Zn'nun toprak solucanı dokularında arttığını, vermikompostta ise azaldığını belirlemiştir. Ayrıca, çalışma sonucunda, $\mathrm{Zn}$ nun E.fetida türü toprak solucanları aracılığıyla ortamdan uzaklaştırılmasının mümkün olabileceği belirtilmektedir. 
Kızılkaya (2005), farklı organik atıklar kullandığg çalışmasında toprağa ilave ettiği $\mathrm{Zn}$ dozlarının $(0,50$, $100,250,500$ ve $1000 \mathrm{mg} \mathrm{kg}^{-1}$ ) toprak solucanı dokularında $\mathrm{Zn}$ akümülasyon miktarı ve toprak solucanı dışkısındaki $\mathrm{Zn}$ miktarı üzerine etkisini araştırdığ 1 çalışma sonucunda; organik atıklar uygulandıktan 21 gün sonra toprak solucanı dokusu ve dışkısındaki en yüksek $\mathrm{Zn}$ miktarını belirlemiştir. $\mathrm{Zn}$ ilave edilen topraklarda toprak solucanı doku ve dişkısında uygulama yapılmamış topraklardan önemli derecede daha yüksek $\mathrm{Zn}$ miktarı saptandığı, en yüksek $\mathrm{Zn}$ miktarının tüm $\mathrm{Zn}$ dozlarında, yüksek $\mathrm{C} / \mathrm{N}$ oranına sahip organik atıklarla (saman ve findık zurufu) uygulama yapılmış topraklardaki toprak solucanlarında olduğunu belirlemiştir.

Azizi ve ark. (2013) tarafindan, aritma çamurlarındaki ağır metal gideriminde Lumbricus rubellus kullanılan araştırma sonucunda, Lumbricus rubellus, arıtma çamuru ve mantar kompostu içeren varyantlarda, uygulamadan 10 hafta sonra aritma çamurunda bulunan ağır metallerden $\mathrm{Cr}, \mathrm{Cd}$ ve $\mathrm{Pb}$ ilk miktarlarından \%90-98.7 daha düşük değerlere ulaşıldığ 1 belirlenir iken, $\mathrm{Cu}$ ve Zn'nun ilk miktarlarından daha yüksek değerde olduğu ortaya konmuştur.

Suthar ve ark. (2014), tarafindan inek gübresi ile $E$. fetida kullanılarak kağıt fabrikasının atıksu arıtma çamurundan ağır metal gideriminin araştırıldığı çalışmada, inek gübresi (100/100), arıtma çamuru: inek gübresi (1:3), arıtma çamuru: inek gübresi (1:2), arıtma çamuru: inek gübresi (1:2), arıtma çamuru: inek gübresi (1: 1), arıtma çamuru: inek gübresi (100/100), arıtma çamuru: inek gübresi (3: 1), arıtma çamuru: inek gübresi (2: 1) varyantları hazırlanarak 60 gün süresince kimyasal parametrelerdeki değişikliklerin araştırıldığ1 çalışma sonucunda; $\mathrm{Cd}(\% 32-37), \quad \mathrm{Cr}(\% 47.3-80.9)$, $\mathrm{Cu}(\% 68.8-88.4)$ ve $\mathrm{Pb}(\% 95.3-97.5)$ miktarlarında azalma, toplam-N, alınabilir $\mathrm{P}$ ve $\mathrm{K}$ seviyelerinde önemli derecede artış meydana geldiği belirlenmiştir. Ayrıca, en iyi giderimin sağlandığ olarak, arıtma çamuru: inek gübresi (2: 1 ve/veya 3: 1) olarak belirlenmiş olup, topraksolucanlarının dokularındaki metallerin birikimlerinin; $\mathrm{mgkg}^{-1} \mathrm{kuru}$ biyokütlede $\mathrm{Pb}$ (8.81-9.69), Cd (2.31-2.71), Cr (20.735.9) ve $\mathrm{Cu}$ (9.94-11.6) olduğu belirlenmiştir.

Li ve ark. (2010), tarafindan domuz gübresi ile beslenen E.fetida türü toprak solucanlarındaki $\mathrm{Cu}, \mathrm{Zn}$, $\mathrm{Pb}$ ve $\mathrm{Cd}$ un biyoakümülasyonları ve bu elementlerin domuz gübresindeki biyoyararlanılabilirliğinin araştırıldığı çalışmada, E.fetida daki biyoakümülasyon

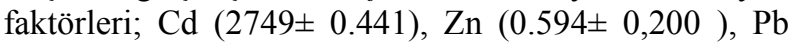
$(0.274 \pm 0.101)$ ve $\mathrm{Cu}(0.076 \pm 0.030)$ olarak belirlenmiştir. Ayrıca $\mathrm{Cu}$, değiştirilebilir Fe-Mn bağlı oksitlerin fraksiyonlarının konsantrasyonları ile açıklanırken, E.fetida nın $\mathrm{Pb}$ ve $\mathrm{Cd}$ konsantrasyonlarındaki değişiklikler, değiştirililebilir fraksiyonların konsantrasyonu ile açıklanmıştır. E.fetida'daki Zn'nun kosantrasyonunun, değiştirilebilir Fe-Mn bağlı oksitler ve bağlı karbonatların konsantrasyonuna bağlı olduğu, doğrusal olmayan regresyon analizi domuz gübresinin değiştirilebilir metal konsatrasyonu ve BAF arasında pozitif logaritmik ilişki olduğu sonucuna varılmıştır.

Liu ve ark., (2012) arıtma çamurundaki ağır metaller üzerindeki toprak solucanı aktivitesinin etkilerini araştırdıkları çalışmada, E.fetida ile vermikompostlamada öncesi ile yapılan karşılaştırma sonucunda; su içeriği, $\mathrm{pH}$ değeri, organik madde miktarının azaldığı, toplam azot içeriğinin arttığı, toplam fosfor ve potasyum içeriğinin azaldı ğ 1 , kullanılabilir azot konsantrasyonu ve kullanılabilir fosfor içeriğinin arttığ $1, \mathrm{Cu}, \mathrm{Ni}, \mathrm{Cd}, \mathrm{Pb}, \mathrm{Zn}$ metallerindeki toplam içeriğinin azaldığı belirlenmiş, vermikompostlama ile ağır metallerin verimli bir şekilde giderildiği ortaya konmuştur.

Pattnaik ve Reddy (2012) tarafindan, kentsel katı atıklar, pazaryeri atıkları ve bitki atıklarındaki $\mathrm{Pb}, \mathrm{Zn}$, $\mathrm{Cd}, \mathrm{Cu}$, ve $\mathrm{Mn}$ ağır metallerinin toprak solucanları ile gideriminin araştırıldığı çalışma sonucunda; Eudrilus eugeniae, Eisenia fetida ve Perionyx excavatus türleri kullanılarak ağır metal gideriminin önemli derecede sağlandığı ortaya konulur iken, E.eugeniae tarafindan üretilen vermikompostun, P.excavatus ve E.fetida tarafından üretilen vermikompost ve komposta göre ağır metal gideriminde daha etkili olduğu sonucuna varılmıştır.

Shaymaa ve ark.,(2010), tarafindan endüstriyel arıtma çamurundan $\mathrm{Pb}, \mathrm{Ni}, \mathrm{Al}$ ağır metallerinin vermikompostlama yöntemi ile gideriminin araştırıldığı; arıtma çamuru: koyun gübresi (20/80), arıtma çamuru: koyun gübresi (50/50), arıtma çamuru: koyun gübresi (80/20), arıtma çamuru: koyun gübresi (100/0) varyantları hazırlanarak 56 günlük çalışma süresi sonunda, $\mathrm{Pb}, \mathrm{Ni}, \mathrm{Al}$ ağır metallerinin sirasiyla \%97, $\% 86, \% 72$ oranında giderimin sağlandığı sonucuna varılmıştır.

\section{SONUÇ ve ÖNERILER}

Doğada (toprakta ve suda) kontrolsüz olarak dağılmış ağır metaller ve bileşiklerini bertaraf etmek çok zor ve pahalıdır (Sezgin, 2012). Topraklardaki metallerin etkisini yok etmek için kazma, katılaştırma, stabilizasyon, toprak yıkama, elektrokinetik ve fitoremediasyon gibi çeşitli teknikler kullanılmaktadır. Kazma ile bertaraf, giderim yapilan yere yeni toprak getirme ihtiyac1 ve arazi doldurma maliyetlerinden dolayı pahalı işlemdir (Tandy ve ark., 2009). Topraktaki ağır metal gideriminde kullanılan mekanik ayırma teknolojileri, pirometalurjik teknolojiler gibi yöntemlerin uygulanması için birtakım ekipman ve donanımın gerekmesi yüksek maliyetlere neden olabilmektedir.

Biyoremediasyon yöntemi diğer yöntemlere kıyasla kirlenmiş su ve toprak alanlarının temizlenmesinde daha ucuz ve gelecek vaat eden bir yöntemdir (Ceyhan ve Esmeray, 2012).

Topraktaki ağır metal kirliliğinin gideriminde toprak solucanlarının kullanılması biyoremediasyon 
yöntemlerinden biri olup, günümüzde pratikte uygulanan bir yöntem değildir.

Konu ile ilgili yapılan çalışmalarda toprak solucanlarının toprakta bulunan ağır metalleri bünyelerinde biriktirdiği sonucuna varılmıştır. Toprak solucanlarının ağır metalleri dokularında biriktirmeleri yanı sıra, topraktaki bitki besin elementini artırma, bitkilerin gelişimine katkıda bulunma, toprağın havalanmasını sağlama, mikrobiyal aktiviteyi arttırma gibi olumlu özellikleri nedeniyle, toprağa ek bir katkı sağlaması açısından yöntemin diğer arıtma teknolojilerine göre toprağa daha yarayışlı olduğu düşünülmektedir.

Ancak, diğer teknolojilere kıyasla daha çevreci ve daha düşük maliyetli olması nedeniyle kullanılabilirliğinin arttırılması için, pratikte kirlenmiş bir toprağa bırakılan toprak solucanların ortama adapte olup olamayacağı, bir süre sonra belirli düzeyde ağır metal kirliliğine maruz kalarak ölmüş toprak solucanlarının topraktan hangi yöntemlerle ayrıştırılacağı gibi konularda birtakım çalışmaların yapılması gerekmektedir. Benzer şekilde, toprakta doğal ortamda ağır metali bünyesinde biriktiren toprak solucanlarının öldükleri zaman toprakta mineralizasyonları ile bünyelerinde biriktirdikleri ağır metali tekrar toprağa verecekleri için, topraktan nasıl uzaklaştırılacağı konuları ile ilgili çalışmalar bulunmamaktadır.

Ayrıca, yapılan çalışmalarda ağır metalin çeşidine göre birikim miktarlarının, farklı toprak solucanı türlerinde farklı miktarlarda olduğu ortaya konmuştur. Dokusunda ağır metal biriktiren toprak solucanlarının kirlenmiş topraklardan hangi yöntemlerle uzaklaştırılacağı konusundaki çalışmaların yetersiz kaldığı düşünülmekte olup, toprak solucanlarının topraktaki ağır metal gideriminde ne derecede verimli olduğu tartışılmaktadır. Yukarıda açıklandığı gibi, konu ile ilgili yetersiz olan kısımların yapılacak bilimsel çalışma sonuçları ile ortaya konması ve bu konulardaki araştırmaların desteklenmesi gerekmektedir.

\section{KAYNAKLAR}

Anonim, 2016. https://www.teachengineering.org/ view_lesson.php?url=collection/cub_/lessons/cub_bi o/cub_bio_lesson06.xml (Erişim tarihi: 10.12.2015).

Azizi, A.B., Lim, M.P.M., Noo, Z.M., Abdullah, N. 2013. Vermiremoval of heavy metal in Sewage sludge by utilising Lumbricus rubellus. Ecotoxicology and Environmental Safety, 90, 13-20.

Bellitürk, K, 2013. Trakya Bölgesi'nde Tarımda Yeni Yaklaşımlar: Solucan Gübresi (Vermikompost) Uygulamaları. Zeytinburnu Tıbbi Bitkiler Bahçesi, Zeytinburnu, İstanbul, s.36-39.

Çağlarırmak, N., Hepçimen, A.Z. 2010. Ağır Metal Toprak Kirliliğinin Gıda Zinciri ve İnsan Sağlığına Etkisi. Akademik Gıda Bilimi ve Teknolojisi Dergisi, 8(2):31-35.
Çobanoğlu, Z., Güler, Ç. 1997. Toprak Kirliliği. Çevre Sağlığı Temel Kaynak Dizisi: 40, Barok Ofset Ltd. Şti., Ankara, 47s.

Ceyhan, N., Esmeray, E. 2012. Petrol Kirliliği ve Biyoremediasyon. Türk Bilimsel Derleme Dergisi, 5(1):95-101.

Dindar, E., Topaç Şağban, F.O. Başkaya, H.S. 2010. Kirlenmiş Toprakların Biyoremediasyon ile Islahı. Uludağ Üniversitesi Mühendislik-Mimarlık Fakültesi Dergisi, 15(2):123-137.

Dindar, E. 2008. Arıtma Çamuru Verilen Tarım Topraklarında Solucan Aktivitesinin Azot Formlarına ve Toprak Enzim Aktivitelerine Etkisi. U.Ü. Fen Bilimleri Enstitüsü, Çevre Mühendisliği Anabilim Dalı, Yüksek Lisans Tezi, Bursa, 139s.

Hepşen Türkay, F.Ş. 2010. Fındık Zurufu Ve Arıtma Çamurunun Solucanlarla Kompostlanması ve Elde Edilen Vermikompostun Sera ve Tarla Koşullarında Toprakların Biyolojik Özelliklerinde Meydana Getirdiği Etkilerin Belirlenmesi. OMÜ Fen Bilimleri Enstitüsü, Toprak Anabilim Dalı, Doktora Tezi, Samsun, 166s.

Kocaer, F.O., Başkaya, S.H.,2003. Metallerle Kirlenmiş Toprakların Temizlenmesinde Uygulanan Teknolojiler. Uludağ Üniversitesi Mühendislik-Mimarlık Fakültesi Dergisi, 8(1): 121-131.

Li, L., Xu, Z., Wu, J., Tian, G.,2010. Bioaccumulation of Heavy Metals in the Earthworm Eisenia Fetida in Relation to Bioavailable Metal Concentrations in Pig Manure. Bioresource Technology, 101: 34303436.

Liu, F., Zhu, P., Xue, J.,2012. Comparative Study on Physical and Chemical Characteristics of Sludge Vermicomposted by Eisenia Fetida. Procedia Environmental Sciences, 16:418-423.

Okcu, M., Tozlu, E., Kumlay, A.M., Pehluvan, M., 2009. Ağır Metallerin Bitkiler Üzerine Etkileri. Alınteri Zirai Bilimler Dergisi, 17:14-26.

Öktüren Asri, F., Sönmez, S. 2006. Ağır Metal Toksisitesinin Bitki Metabolizması Üzerine Etkileri. Derim, 23(2):36-45.

Paggio, L. Vrscaj, B., Hepperle, E., Schulın R., Ajmone Marsan, F.,2008. Introducing a method of human health risk evaluation for planning and soil quality management of heavy metal-polluted soilsAn example from Grugliasco (Italy). Landscape and Urban Planning, 88:64-72.

Pattnaik, S., Reddy, M.V. 2012. Remediation of heavy metals from urban waste by vermicomposting using earthworms: Eudrilus eugeniae, Eisenia fetida and Perionyx excavatus. International Journal of Environment and Waste Management, 10(2):284-296.

Pelfrene, A., Detriche, S., Douay, F. 2015. Combining spatial distribution with oral Bioaccessibility of metals in smelter-impacted soils: implications for human health risk assessment. Environ Geochem Health, 37:49-62. 
Sezgin, N. 2012. Endüstriyel Arıtma Çamurlarından Ağır Metal Gideriminin İncelenmesi. İ.Ü. Fen Bilimleri Enstitüsü Çevre Mühendisliği Anabilim Dalı, Doktora Tezi, İstanbul, 140s.

Shaymaa, M., Ahmed, H., Norli, I., Morad, N., Mahamad Hakimi, I. 2010. Removal of Aluminium, Lead and Nickel From Industrial Sludge Via Vermicomposting Process. World Applied Sciences Journal,10(11):1296-1305.

Suthar, S., Sajwan, P., Kumar, K. 2014. Vermiremediation of Heavy Metals in Wastewater Sludge from Paper and Pulp Industry Using Earthworm Eisenia Fetida. Ecotoxicology and Environmental Safety, 109:177-184.
Tandy, S., Healey, J.R., Nason, M.A., Williamson, J.C., Jones, D.L. 2009. Remediation of Metal polluted mine soil with compost: Co-composting versus incorporation. Environmental Pollution, 157:690-697.

Vanlı, Ö., Yazgan, M. 2008. Ağır metallerle Kirlenmiş Topraklarin Temizlenmesinde Fitoremediasyon Tekniği. http://www.tarimsal.com. (Erişim tarihi: 05.04.2016)

Vural, H., 1993. Ağır Metal İyonlarının Gıdalarda Oluşturduğu Kirlilikler. Çevre Dergisi, 8:3-8.

Wuana, R.A., Okieimen, E.F. 2011. Heavy Metals in Contaminated Soils: A Review of Sources, Chemistry, Risks and Best Available Strategies for Remediation. International Scholarly Research Network ISRN Ecology, 402647, 20. 